\title{
Treatment of bacterial respiratory infections
}

\author{
AD van Eyk \\ Division of Pharmacology, Department of Pharmacy and Pharmacology, School of Therapeutic Sciences \\ Faculty of Health Sciences, University of Witwatersrand, Johannesburg \\ Corresponding author: Armorel.vanEyk@wits.ac.za
}

Acute respiratory tract infections are one of the most common reasons that result in general practitioner consultations. Viruses are the most common cause of both upper- and lower respiratory tract infections, however pneumonia is usually bacterial in origin. When from a bacterial origin, S. pneumoniae, non-typical $H$. influenzae and $M$. catarrhalis are mostly the cause of acute otitis media, acute bacterial rhinosinusitis and acute exacerbations of chronic bronchitis, while $S$. pyogenes are usually the presenting organisms in acute pharyngotonsillitis. B. pertussis, C. pneumoniae or M. pneumoniae are common organisms associated with acute bronchitis and community-acquired pneumonia (atypical). Pneumonia is a serious life-threatening condition, and organisms mostly associated with it include S. pneumoniae, S. aureus, H. influenzae type b, K. pneumoniae, Legionella species or $P$. jirovecii. Common symptoms and signs include coughing, facial pain, fever, nasal congestion, sore throat, dyspnoea, and tachypnoea. Most of the acute uncomplicated respiratory tract infections are self-limiting in nature. It is in many instances a challenge to distinguish between acute bronchitis and pneumonia because of the similarity in presenting symptoms. Antibiotics are in many instances inappropriately prescribed to treat the infections resulting in the burden of antibiotic resistance patterns within the community. Treatment options are usually amoxicillin, amoxicillin-clavulanic acid or the 2nd or 3rd generation cephalosporins.

Keywords: Bacterial respiratory tract infections, Upper respiratory tract infections, Lower respiratory tract infections, Pneumonia, Otitis Media

\section{Acute Respiratory Tract Infections (ARTIs)}

Acute respiratory tract infections (ARTIs) are one of the most common reasons for consultation with a general practitioner on an outpatient basis. ${ }^{1-3}$ ARTIs can be classified further into upper- and lower respiratory tract infections. ${ }^{4}$ Acute otitis media (AOM), pharyngotonsillitis, acute bacterial rhinosinusitis and the common cold form part of upper respiratory tract infections (URTIs), while acute bronchitis, acute exacerbations of chronic bronchitis and pneumonia form part of lower respiratory tract infections (LRTIs). ${ }^{1-5}$ The causes of most URTIs and acute bronchitis are viral in nature, with bacteria responsible for less than $10 \%$ of these infections. ${ }^{1-3,5-9}$ The causes of pneumonia may be viral or bacterial in nature. ${ }^{10,11}$ Clinical signs and symptoms of URTIs are varied and include cough, fever, nasal congestion, otalgia, facial pain, sore throat, headache and fatigue. ${ }^{1-3,6,7}$ Acute LRTIs (presenting symptoms 21 days) usually have cough as a presenting symptom together with other symptoms including fever, dyspnoea, and tachypnoea. ${ }^{10}$ Although acute URTIs and acute bronchitis are mostly viral in nature and are self-limiting diseases, antibiotics are in many instances inappropriately prescribed by health care providers in the mistaken belief that these agents decrease the time span of the illness, improve symptoms and prevent further complications. The prescribing of antibiotics erroneously under conditions where they are of no benefit may cause more harm than good and contributes to the emergence of bacterial resistance leading to a serious public health threat. $2,6,8,9,10,12,13$

\section{Acute Upper Respiratory Tract Infections (AURTIs)}

\section{Acute Otitis Media (AOM)}

Acute otitis media occurs very commonly during childhood. Presenting signs and symptoms include otalgia, hearing loss and pyrexia, with the possibility of concurrent nausea and dizziness. Due to the overlap of symptoms with other conditions, AOM could be easily misdiagnosed. However, the presence of a middle ear effusion and in the case of suppuration a red, bulging, immobile and oedematous tympanic membrane will confirm the diagnosis. ${ }^{6,712}$ Causative organisms are mainly Streptococcus pneumoniae, non-typical Haemophilus influenzae and Moraxella catarrhalis. ${ }^{1,5,6,7,12}$ Due to the administration of the Prevnar (PCV7) vaccine to children since 2009 as well as the Prevnar (PCV-13) vaccine since 2011, Haemophilus influenzae has become the most frequent isolated middle ear pathogen in AOM infections. Many of the $H$. influenzae produce $\beta$-lactamases leading to penicillin resistance, especially when antibiotics were used recently. ${ }^{6,12}$ Neonates diagnosed with $\mathrm{AOM}$ and fever require evaluation for sepsis. Coliforms, group B $\beta$-haemolytic streptococci and Staphylococcus aureus are usually causative agents for neonatal AOT. ${ }^{6}$ AOT usually resolves spontaneously and it is recommended that symptoms be treated symptomatically and antibiotic therapy be delayed for a period of 48 hours. Antibiotic therapy is recommended under the following conditions: bulging tympanum, temperature $>38^{\circ} \mathrm{C}$, worsening of symptoms, AOM patients with limited access to healthcare, recurrent AOM, immunocompromised patients, neonates, structural ENT 
abnormalities, immunological abnormalities, pain $>48$ hours, children in day care or siblings of children that attend day care facilities. ${ }^{6}$ Treatment options include amoxicillin, amoxicillinclavulanic acid, cephalosporins or macrolides/azalides, and treatment duration is 5 or 7 days (Table I). 1,4-7,12,14-16

\section{Acute Pharyngotonsillitis (APT)}

This condition is caused by inflammation of the pharyngeal wall. Presenting signs and symptoms include dysphagia, sore throat, halitosis, fever, erythema, nausea, abdominal pain, exudates, tender enlarged anterior cervical lymph nodes and palatal petechiae. ${ }^{2-4,6-8,12,14,16}$ The major cause of pharyngitis is viral in nature with only a small percentage $(5-30 \%)$ caused primarily by group A $\beta$-haemolytic streptococci (GABHS), Streptococcus pyogenes. The presence of $S$. pyogenes should be confirmed by a throat culture. Primarily pharyngitis, whether viral of bacterial in nature, resolves spontaneously and antibiotic treatment is only considered to prevent acute rheumatic fever. Treatment options upon confirmation of a S. pyogenes infection are oral penicillin VK, IM benzathine benzylpenicillin, oral amoxicillin, cephalosporins or macrolides and treatment duration 10 days (Table I). 2,3,4-8,12,14-16

\section{Acute bacterial rhinosinusitis (ABRS)}

ABRS is a condition characterised by inflammation in the nasal and paranasal sinuses. Presenting signs and symptoms include either anterior or postnasal discharge or nasal obstruction with or without facial pain/pressure or changes in smell. Causative organisms isolated from the maxillary sinuses are the same as those identified in AOM. With the usage of the PCV, H. influenzae isolates have increased. Antibiotic therapy is only recommended if symptoms last more than 10 days, lasting purulence or fever is present, or symptoms become worse in less than 10 days (second sickening). Recent antibiotic usage increases the risk of resistant bacteria which complicates treatment options. Antibiotic treatment options recommend amoxicillin, amoxicillinclavulanic acid or cephalosporins, or alternatively macrolides or fluoroquinolones and treatment duration 5 days (Table I). ${ }^{2-7,12,14-16}$

\section{Acute Lower Respiratory Tract Infections (ALRTIs)}

\section{Acute Bronchitis (AB)}

Usually, acute bronchitis follows an upper respiratory tract infection and is characterized by inflammation of the midsized and large airways. Symptoms include an acute, persistent productive or non-productive cough and may be accompanied by fever and chest pain. Additional symptoms are usually a sore throat and runny nose. It is usually a self-limiting condition and typically viral in origin (> 90\%), lasting in the region of 7-14 days. A bacterial infection is usually uncommon but a secondary bacterial infection is suspected when the condition is severe and persists for longer than 7 days. Antibiotic therapy is not usually indicated for acute bronchitis. 2,7,9,12-15,17 The signs and symptoms of acute bronchitis and pneumonia are in many instances difficult to differentiate with the result that general practitioners prescribe antibiotic treatment inappropriately based on patient's expectations and to treat a possible case of pneumonia.9,13 Due to the large extent to which antibiotics are prescribed for acute bronchitis that are viral in origin, the development of antibiotic resistance in the community has escalated. Whether an antibiotic should be prescribed will depend on how severe the infection is, estimated risk factors and parenchymal/bacterial markers. Organisms responsible in the event of a bacterial cause $(<10 \%)$ are Bordetella pertussis, Chlamydia pneumoniae or Mycoplasma pneumoniae. Treatment options in the case of these bacterial causes are the macrolide class of antibiotics (Table I). ${ }^{7,9,13-15,17}$

\section{Acute exacerbations of chronic bronchitis (AECB)// Chronic obstructive pulmonary disease (COPD) (AECOPD)}

Presenting symptoms and signs include a productive cough lasting more than 3 months within a year for 2 consecutive years or more, worsening dyspnoea, greater sputum purulence and greater sputum volume. Presenting symptoms of COPD include obstruction of the airways, chronic bronchitis, emphysema, asthma and bronchiectasis. This condition presents usually in adults and rarely in children. Organisms associated with AECB/ AECOPD are mostly viral in nature, however the most common bacteria showing causality include Streptococcus pneumoniae, non-typical Haemophilus influenzae and Moraxella catarrhalis. When a bacterial infection is suspected, treatment options include amoxicillin, amoxicillin-clavulanic acid or ceftriaxone over a 5 day period (Table I). ${ }^{13-16,18-23}$

\section{Pneumonia}

Pneumonia is a serious acute lower respiratory tract infection often presenting similar symptoms to acute bronchitis. It is a major cause of death in young children $<2$ years of age. Children ( $<5$ years of age), adults ( $>65$ years) and immunocompromised persons are at a higher risk of contracting the disease. It causes infection of lung parenchyma and there is clinical and/ or radiological evidence of consolidation in parts of the lung. Presenting symptoms and signs include fever $\left(>38^{\circ} \mathrm{C}\right)$, chills, painful breathing, tachypnoea and cough. Pneumonia is usually bacterial in nature and due to the high risk of morbidity, the appropriate antibiotic treatment should be initiated early on. Causative organisms include Streptococcus pneumoniae, Staphylococcus aureus, Haemophilus influenzae type b, Klebsiella pneumoniae as well as the atypical pathogens Mycoplasma pneumoniae, Chlamydia pneumoniae and Legionella species. Pneumocystisjirovecii is the most common cause of opportunistic infections in HIV-positive patients. Since the increased usage of vaccines against $H$. influenzae type $b$ and pneumococci, these organisms as the cause of the disease have diminished. Initial empiric treatment will depend on the patient's age, treatment setting, comorbid diseases, drug allergies and antibiotic usage within the previous 90 days (Table I). 1,10,11,13-17,21,23-26

\section{Conclusion}

Both children and adults commonly experience acute respiratory tract infections. Most are viral in nature, self-limiting and do not require antibiotic therapy. In the event of symptoms becoming more severe and a bacterial origin being suspected, antibiotic therapy can be initiated. In the case of bacterial pneumonia, antibiotic therapy should be started early on so as to decrease the risk of morbidity. 
Table I. Main antibiotic treatment options for Upper and Lower Respiratory Tract Infections of bacterial origin. ${ }^{1,2-8,10,12-19,21,23,25-27}$

Alternative treatment

Acute Otitis Media (AOM)

AND

Acute bacterial rhinosinusitis (ABRS)
S. pneumoniae, non-typeable $H$. influenzae (NTHi), M. catarrhalis

Causative organism
Satarrhalis
noumoniae,
influenzae (NTHi), M.
cable

\begin{tabular}{l} 
Children: \\
\hline Duration: 5 days ( $>2$ years of age) - 7 \\
days (< 2 years of age) \\
Doses: Every 12 hours \\
Amoxicillin (PO $80-90 \mathrm{mg} / \mathrm{kg} / \mathrm{d}$ ) \\
OR \\
Amoxicillin-clavulanic acid (PO \\
$90 \mathrm{mg} / \mathrm{kg} / \mathrm{d}$ amoxicillin-6.4 mg/kg/d \\
clavulanic acid) \\
OR \\
Cefuroxime axetil (PO $30 \mathrm{mg} / \mathrm{kg} / \mathrm{d}$ ) \\
OR \\
Cefpodoxime (PO $16 \mathrm{mg} / \mathrm{kg} / \mathrm{d}$ )
\end{tabular}

\section{Failed initial therapy after}

\section{8-72 hours:}

Amoxicillin-clavulanic acid (PO $90 \mathrm{mg} /$ $\mathrm{kg} / \mathrm{d}$ amoxicillin-6.4 mg/kg/d clavulanic acid) every 12 hours

Duration: $5-7$ days ( $>2$ years of age);

$7-10$ days $(<2$ years of age)

OR

Ceftriaxone (IM or IV $50 \mathrm{mg} / \mathrm{kg} / \mathrm{d}$ once daily for 3 days)*

\begin{tabular}{ll}
\hline Adults: & Adults: (Penicillin allergy) \\
\hline Duration: 5 days & Duration: 5 days \\
Amoxicillin (PO 1000 mg every 8 hours) & Telithromycin (PO $800 \mathrm{mg}$ once daily) \\
OR & OR \\
Amoxicillin-clavulanic acid (PO 2000 mg & Gemifloxacin (PO $320 \mathrm{mg}$, once daily) \\
-125 mg clavulanic acid every 12 hours) & OR \\
OR & Levofloxacin (PO 500 mg, every 12 \\
Cefuroxime axetil (PO 1000 mg every & hours or 750 mg once daily) \\
12 hours) & OR \\
OR & Moxifloxacin (PO 400 mg once daily) \\
Cefpodoxime (PO 400 mg every 12 & OR \\
hours) & Azithromycin (PO 500 mg once daily for \\
& 3 days)
\end{tabular}

Failed initial therapy after 48-72 hours:

Duration: 5-7 days

Amoxicillin-clavulanic acid (PO 2000 mg Adults: (Penicillin allergy)

$-125 \mathrm{mg}$ clavulanic acid every 12 hours) Telithromycin (PO $800 \mathrm{mg}$ once daily) OR

Ceftriaxone (IM or IV $1000-2000 \mathrm{mg}$ once daily for $3-5$ days)

Children: (Type 1 penicillin allergy)

Levofloxacin (PO $20 \mathrm{mg} / \mathrm{kg} / \mathrm{d}$, every 12

hours for 5 days)

Children: (Non-type 1 penicillin

allergy)

Azithromycin (PO $10 \mathrm{mg} / \mathrm{kg} / \mathrm{d}$, once

daily for 3 days)

OR

Clarithromycin (PO 15-30 mg/ kg/d,

every 12 hours for 5 days)

OR

Erythromycin estolate (PO $40 \mathrm{mg} / \mathrm{kg} / \mathrm{d}$, every 6 hours for 5 days)

\section{Failed initial therapy after \\ 48-72 hours:}

Clarithromycin (PO 90-150 mg/ kg/d,

every 8 hours for 5 days)

+ -

2nd or 3rd generation cephalosporin for 5-7 days

Failed initial therapy after

48-72 hours:

Duration: 5-7 days

OR

Gemifloxacin (PO 320 mg, once daily)

OR

Levofloxacin (PO $500 \mathrm{mg}$, every 12

hours or $750 \mathrm{mg}$ once daily)

OR

Moxifloxacin (PO $400 \mathrm{mg}$ once daily)

OR

Clindamycin (PO $450 \mathrm{mg}$ every 8 hours)

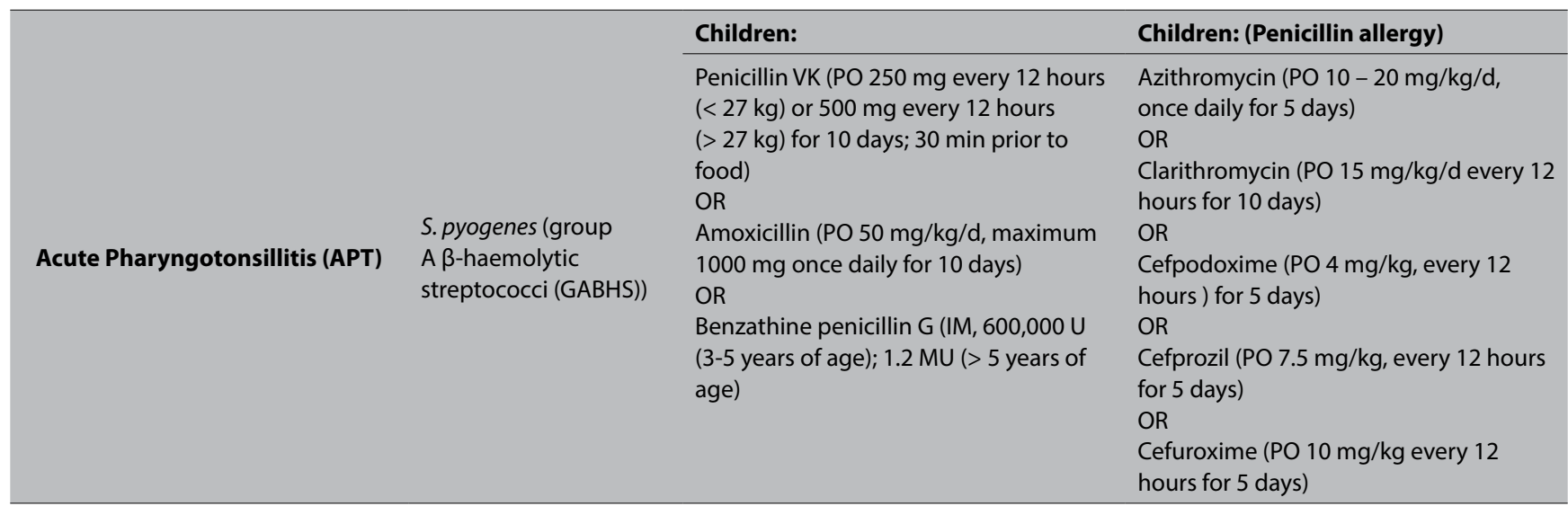


Table I. Main antibiotic treatment options for Upper and Lower Respiratory Tract Infections of bacterial origin (CONT.). ${ }^{1,2-8,10,12-19,21,23,25-27}$

\begin{tabular}{|c|c|c|c|}
\hline Category & Causative organism & First line treatment & Alternative treatment \\
\hline Acute Pharyngotonsillitis (APT) & $\begin{array}{l}\text { S. pyogenes (group } \\
\text { A } \beta \text {-haemolytic } \\
\text { streptococci (GABHS)) }\end{array}$ & $\begin{array}{l}\text { Adults: } \\
\text { Penicillin VK (PO: } 500 \mathrm{mg} \text { every } 12 \text { hours } \\
\text { for } 10 \text { days; } 30 \mathrm{~min} \text { prior to food) } \\
\text { OR } \\
\text { Amoxicillin (PO } 500 \text { - } 1000 \mathrm{mg} \text { every } \\
12 \text { hours or } 50 \mathrm{mg} / \mathrm{kg} / \mathrm{d} \text { once daily, } \\
\text { maximum } 3000 \mathrm{mg} \text { for } 10 \text { days) } \\
\text { OR } \\
\text { Amoxicillin-clavulanic acid (PO } 500 \mathrm{mg} \\
-125 \mathrm{mg} \text { clavulanic every } 8 \text { hours for } \\
10 \text { days) } \\
\text { OR } \\
\text { Benzathine penicillin G (IM, } \\
1.2 \mathrm{MU} \text {, single dose) }\end{array}$ & $\begin{array}{l}\text { Adults: (Penicillin allergy) } \\
\text { Azithromycin (PO } 500 \mathrm{mg} \text {, once daily } \\
\text { for } 3 \text { days) } \\
\text { OR } \\
\text { Clarithromycin (PO } 500 \mathrm{mg} \text { every } \\
12 \text { hours or } 500 \mathrm{mg} \text { modified- release } \\
\text { once daily, for } 10 \text { days) } \\
\text { OR } \\
\text { Clindamycin (PO } 300 \mathrm{mg} \text { every } 8 \text { hours } \\
\text { for } 10 \text { days) } \\
\text { OR } \\
\text { Cefpodoxime (PO } 100 \mathrm{mg} \text {, every } \\
12 \text { hours) for } 5 \text { days) } \\
\text { OR } \\
\text { Cefprozil (PO } 500 \mathrm{mg} \text {, every } 12 \text { hours } \\
\text { for } 5 \text { days) } \\
\text { OR } \\
\text { Cefuroxime (PO } 250 \mathrm{mg} \text {, every } 12 \text { hours } \\
\text { for } 5 \text { days) } \\
\text { OR } \\
\text { Telithromycin (PO } 800 \text { mg, once daily } \\
\text { for } 5 \text { days) }\end{array}$ \\
\hline
\end{tabular}

Acute uncomplicated:

Antibiotic therapy not indicated except

in the presence of underlying COPD

\begin{tabular}{|c|c|c|c|}
\hline & \\
\hline \multirow{4}{*}{ Acute Bronchitis (AB) } & \multirow{4}{*}{$\begin{array}{l}\text { B. pertussis, } C \text {. } \\
\text { pneumoniae or } \\
\text { M. pneumoniae }\end{array}$} & Children: & Children: > 8 years of age \\
\hline & & $\begin{array}{l}\text { Azithromycin (PO } 10-20 \mathrm{mg} / \mathrm{kg} / \mathrm{d} \text {, } \\
\text { once daily for } 5 \text { days) } \\
\text { OR } \\
\text { Clarithromycin (PO } 15 \mathrm{mg} / \mathrm{kg} / \mathrm{d} \text { every } \\
12 \text { hours for } 7-14 \text { days) }\end{array}$ & $\begin{array}{l}\text { Doxycycline (PO } 2 \mathrm{mg} / \mathrm{kg} \text { (maximum } \\
100 \mathrm{mg} \text { ) every } 12 \text { hours for } 5 \text { days) }\end{array}$ \\
\hline & & Adults: & Adults: \\
\hline & & $\begin{array}{l}\text { Azithromycin (PO } 500 \mathrm{mg} \text {, once daily } \\
\text { for } 3 \text { days) } \\
\text { OR } \\
\text { Clarithromycin (PO } 500 \mathrm{mg} \text { every } \\
12 \text { hours or } 500 \mathrm{mg} \text { modified release } \\
\text { once daily, for } 10 \text { days) }\end{array}$ & $\begin{array}{l}\text { Doxycycline (PO } 100 \mathrm{mg} \text { every } 12 \text { hours } \\
\text { for } 5 \text { days) }\end{array}$ \\
\hline $\begin{array}{l}\text { Acute exacerbations of chronic } \\
\text { bronchitis/COPD (AECB/AECOPD) }\end{array}$ & $\begin{array}{l}\text { S. pneumoniae, } \\
\text { non-typeable } H \text {. } \\
\text { influenzae (NTHi), } \\
\text { M. catarrhalis }\end{array}$ & $\begin{array}{l}\text { Duration: } 5 \text { days } \\
\text { Amoxicillin (PO } 500 \mathrm{mg} \text { every } 8 \mathrm{~h} \text { ) } \\
\text { OR } \\
\text { Amoxicillin-clavulanic acid (PO } 1000 \mathrm{mg} \\
\text { every } 12 \text { hours or } 1200 \mathrm{mg} \text { (IV) every } \\
8 \text { hours) } \\
\text { OR } \\
\text { Ceftriaxone (1000 mg (IV) daily) }\end{array}$ & $\begin{array}{l}\text { Doxycycline (PO } 200 \mathrm{mg} \text { on } 1 \text { st day, } \\
\text { then } 100 \mathrm{mg} \text { per day or } 100 \mathrm{mg} \text { every } \\
12 \text { hours for } 5 \text { days) } \\
\text { OR } \\
\text { Moxifloxacin (PO } 400 \mathrm{mg} \text { once a day) } \\
\text { OR } \\
\text { Levofloxacin (PO } 750 \mathrm{mg} \text { once a day or } \\
500 \mathrm{mg} \text { every } 12 \text { hours) }\end{array}$ \\
\hline \multirow{5}{*}{ Pneumonia } & \multirow{5}{*}{$\begin{array}{l}\text { S. pneumoniae, } S \text {. } \\
\text { aureus, H. influenzae } \\
\text { type } b, \\
\text { K. pneumoniae, } M \text {. } \\
\text { pneumoniae, } C . \\
\text { pneumonia, } \\
\text { Legionella species }\end{array}$} & $\begin{array}{l}\text { Duration: } 5-7 \text { days; } 14 \text { days for severe } \\
\text { Legionella infections }\end{array}$ & $\begin{array}{l}\text { Duration: } 5-7 \text { days; } 14 \text { days for severe } \\
\text { Legionella infections }\end{array}$ \\
\hline & & Children: & Children: \\
\hline & & $\begin{array}{l}\text { Non-severe: Amoxicillin } \\
\text { (PO } 45 \mathrm{mg} / \mathrm{kg} / \mathrm{d} \text { every } 12 \text { hours) } \\
\text { Severe: Ceftriaxone (IM } 80 \mathrm{mg} / \mathrm{kg} / \mathrm{d} \\
\text { single dose) * }\end{array}$ & $\begin{array}{l}\text { Non-severe: Azithromycin } \\
\text { (PO } 10 \mathrm{mg} / \mathrm{kg} / \mathrm{d} \text {, once daily for } 3 \text { days) } \\
\text { OR } \\
\text { Clarithromycin (PO } 15-30 \mathrm{mg} / \mathrm{kg} / \mathrm{d} \text {, } \\
\text { every } 12 \text { hours for } 5 \text { days) } \\
\text { OR } \\
\text { Erythromycin estolate (PO } 40 \mathrm{mg} / \mathrm{kg} / \mathrm{d} \text {, } \\
\text { every } 6 \text { hours for } 5 \text { days) }\end{array}$ \\
\hline & & $\begin{array}{l}\text { Patients }<65 \text { years, no } \\
\text { co-morbidities, no usage of } \\
\text { antibiotics within prior } 90 \text { days: }\end{array}$ & $\begin{array}{l}\text { Patients }<65 \text { years, no } \\
\text { co-morbidities, no usage of } \\
\text { antibiotics within prior } 90 \text { days: }\end{array}$ \\
\hline & & $\begin{array}{l}\text { Outpatient: Amoxicillin (PO } 1000 \text { mg, } \\
\text { every } 8 \text { h) }\end{array}$ & $\begin{array}{l}\text { Outpatient: Moxifloxacin (PO } 400 \mathrm{mg} \\
\text { once a day) } \\
\text { OR } \\
\text { Levofloxacin (PO } 750 \mathrm{mg} \text { once a day or } \\
500 \text { mg every } 12 \text { hours) }\end{array}$ \\
\hline
\end{tabular}


Table I. Main antibiotic treatment options for Upper and Lower Respiratory Tract Infections of bacterial origin (CONT.). ${ }^{1,2-8,10,12-19,21,23,25-27}$

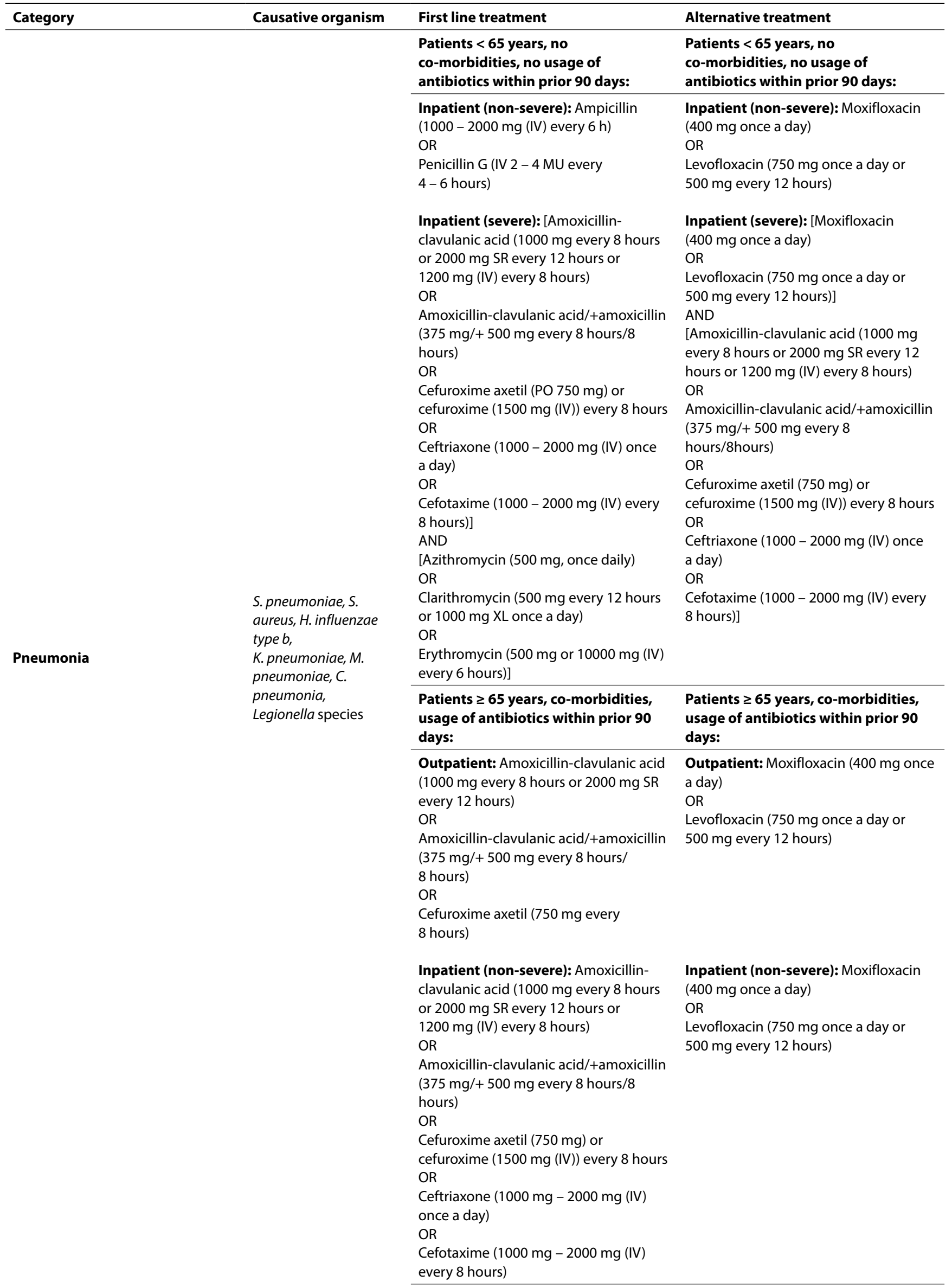


Table I. Main antibiotic treatment options for Upper and Lower Respiratory Tract Infections of bacterial origin (CONT.). ${ }^{1,2-8,10,12-19,21,23,25-27}$

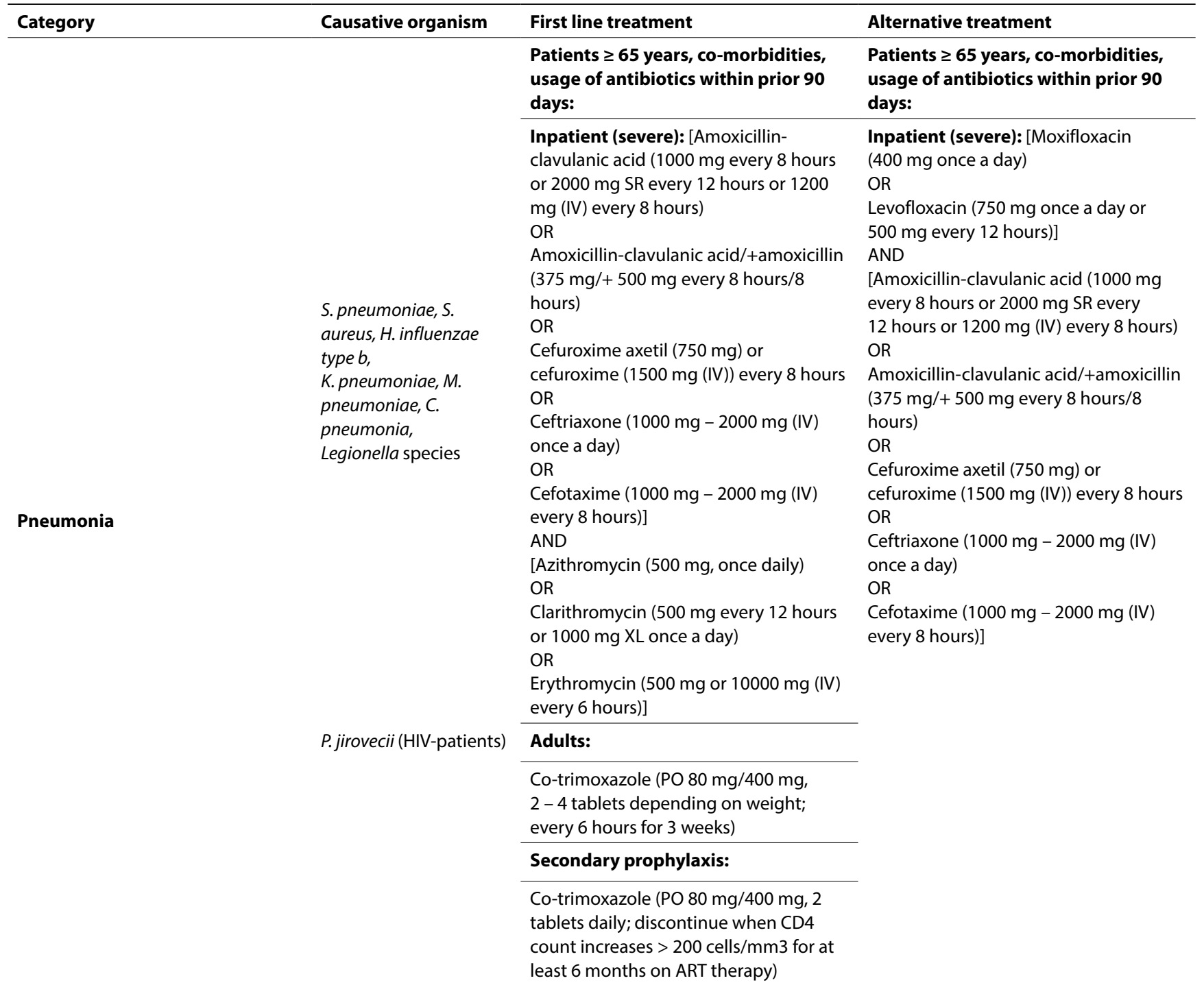

*Ceftriaxone (Administer even in jaundiced neonates for serious bacterial infections. Avoid administering calcium-containing IV fluid with ceftriaxone. For infants $\leq 28$ days old, do not administer calcium-containing IV fluid within 48 hours of administering ceftriaxone. For infants $>28$ days old calcium-containing IV fluid and ceftriaxone can be administered sequentially, however IV lines have to be flushed with saline before and after.)

\section{References}

1. Paul SP, Wilkinson R, Routley C. Management of respiratory tract infections in children. Nursing: Research and Reviews. Dec 2014 [accessed on 15 Jan 2019];4:135-48. Available from: https://doi.org/10.2147/NRR.S43033

2. Harris AM, Hicks LA, Qaseem A. Appropriate Antibiotic Use for Acute Respiratory Tract Infection in Adults: Advice for High-Value Care From the American College of Physicians and the Centers for Disease Control and Prevention. Ann Intern Med. 2016 [accessed on 15 Jan 2019];164:425-34. doi: 10.7326/M15-1840. Available from: http://www.ashnha.com/wp-content/uploads/2015/05/ACP-URIguidelines-1.pdf

3. Yoon YK, Park C-S, Kim JW, et al. Guidelines for the Antibiotic Use in Adults with Acute Upper Respiratory Tract Infections. Infect Chemother. 2017 [accessed on 15 Jan 2019];49(4):326-52. Available from: https://doi.org/10.3947/ ic.2017.49.4.326

4. Zeng L, Zhang L, Hu Z, et al. Systematic Review of Evidence-Based Guidelines on Medication Therapy for Upper Respiratory Tract Infection in Children with AGREE Instrument. PLoS ONE. Feb 2014 [accessed on 15 Jan 2019];9(2):e87711. doi: 10.1371/journal.pone.0087711. Available from: https://www.ncbi.nlm.nih.gov/ pmc/articles/PMC3930557/pdf/pone.0087711.pdf

5. Ferrara $P$, Cutrona $C$, Sbordone $A$. Which treatment for upper respiratory tract infections? Ital J Pediatr. 2015 [accessed on 15 Jan 2019];41(Suppl 2):A31. doi: 10.1186/1824-7288-41-S2-A31. Available from: http://www.ijponline.net/ content/41/S2/A31
6. Brink AJ, Cotton MF, Feldman $C$, et al. Updated recommendations for the management of upper respiratory tract infections in South Africa. S Afr Med J. May 2015 [accessed on 15 Jan 2019];105(5):345-52. Available from: http://www. samj.org.za/index.php/samj/article/view/9995

7. Best Practices in the Management of Patients with Pharyngitis. California Medical Association Foundation: Acute Infection Guideline Summary 2016-17 (Pediatric). [Accessed on 11 Feb 2019]. Available from: https://www. ohiohospitals.org/OHA/media/Images/Patient\%20Safety\%20and\%20Quality/ Documents/Ant\%20Stewardship-CDI/compendium-pediatric-2016-11x17-finalweb.pdf

8. Cotton MF, Innes S, Jaspan H, Madide A, Rabie H. Management of upper respiratory tract infections in children. S Afr Fam Pract (2004). 2008 [accessed on 15 Jan 2019];50(2):6-12. Available from: https://www.ncbi.nlm.nih.gov/pmc/ articles/PMC3098742/pdf/nihms256624.pdf

9. Steele K, Gormley G, Webb C H. Management of adult lower respiratory tract infection in primary care [Editorial]. Thorax 2001 [accessed on 15 Jan 2019];56:87-8. Available from: https://thorax.bmj.com/content/56/2/87

10. Feldman C, Brink A, Bateman GA, Maartens G, Bateman ED. Working Group of the South African Thoracic Society. Management of Community-Acquired Pneumonia in Adults [Guideline]. S Afr Med J. Dec 2007 [accessed on 15 Jan 2019];97(12):1296-1306. Available from: http://www.samj.org.za/index.php/ samj/article/view/515

11. Roomaney RA, Pillay-van Wyk V, Awotiwon OF, et al. Epidemiology of lower respiratory infection and pneumonia in South Africa (1997-2015): a systematic 
review protocol. BMJ Open. 2016 [accessed on 15 Jan 2019];6:e012154. doi: 10.1136/bmjopen-2016-012154. Available from: https://www.ncbi.nlm.nih. gov/pmc/articles/PMC5030548/.

12. Wong DM, Blumberg DA, Lowe LG. Guidelines for the use of antibiotics in acute upper respiratory tract infections. Am Fam Physician. Sept 2006 [accessed on 5 Jan 2019];74(6):956-66. Available from: https://www.aafp.org/afp/2006/0915/ p956.pdf

13. Ỗrtqvist Á. Treatment of community-acquired lower respiratory tract infections in adults. Eur Respir J. 2002 [accessed on 15 Jan 2019];20:Suppl.36:40s-53s. doi: 10.1183/09031936.02.00309002. Available from: https://erj.ersjournals.com/ content/20/36_suppl/40s.long

14. Wasserman S, Boyles T, Mendelson M. A pocket guide to antibiotic prescribing for adults in South Africa. On Behalf of the South African antibiotic stewardship programme (SAASP). Nov 2015 [accessed on 15 Jan 2019];1-60. Available from: https://www.fidssa.co.za/Content/Documents/SAASP_Antibiotic_ Guidelines_2015.pdf

15. Republic of South Africa. Essential drugs programme. Primary Healthcare Standard Treatment Guideline and Essential Medicine List. 6th ed. Republic of South Africa: National Department of Health. 2018 [accessed on 15 Jan 2019];Chs 17,19. Available from: https://www.idealhealthfacility.org.za/docs/ guidelines/STG\%20and\%20EML\%20PHC\%202018.pdf

16. Rossiter D, Blockman M, Barnes $K$, et al. editors. General anti-infectives for systemic use. Antibacterials for systemic use. South African Medicines Formulary, 12th ed. 2016;275-306.

17. Best Practices in the Management of Patients with Acute Bronchitis/Cough. California Medical Association Foundation: Acute Infection Guideline Summary 2016-17 (Adult). [Accessed on 11 Feb 2019]. Available from: https://www. ohiohospitals.org/OHA/media/Images/Patient\%20Safety\%20and\%20Quality/ Documents/Ant\%20Stewardship-CDI/compendium-adult-2016-11x17-finalweb.pdf

18. NICE National Institute for Health and Care Excellence: COPD (acute exacerbation): antimicrobial prescribing. NICE. July 2018 [accessed on 12 Feb 2019]. Available from: https://www.nice.org.uk/guidance/ng114/documents/ draft-guideline-2

19. Auwaerter PG, Bartlett JG. Chronic Bronchitis, Acute Exacerbations. Johns Hopkins ABX Guide. [Accessed on 12 Feb 2019]. Available from: https://www.
hopkinsguides.com/hopkins/view/Johns_Hopkins_ABX_Guide/540124/5/ Chronic_Bronchitis_Acute_Exacerbations\&ti $=0$

20. Moussaoui REl, Roede BM, Speelman P, Bresser P, Prins JM, Bossuyt PMM. Short-course antibiotic treatment in acute exacerbations of chronic bronchitis and COPD: a meta-analysis of double-blind studies. Thorax. 2008 [accessed on 11 Feb 2019];63:415-22. doi: 10.1136/thx.2007.090613. Available from: https:// thorax.bmj.com/content/63/5/415.long

21. Woodhead M, Blasi F, Ewig S, et al. Joint Taskforce of the European Respiratory Society and European Society for Clinical Microbiology and Infectious Diseases. Clin Microbiol Infect. Nov 2011 [accessed on 15 Jan 2019];17(Suppl 6):E1-E58. Available from: https://www.clinicalmicrobiologyandinfection.com/article/ S1198-743X(14)61404-X/pdf

22. Viniol C, Vogelmeier CF. Exacerbations of COPD. Eur Respir Rev. 2018 [accessed on 11 Feb 2019];27: 170103. Available from: https://doi. org/10.1183/16000617.0103-2017

23. Balter M, Weiss K. Treating acute exacerbations of chronic bronchitis and community-acquired pneumoni. How effective are respiratory fluoroquinolones? Can Fam Physician. Oct 2006 [accessed on 11 Feb 2019]; 52:1236-42. Available from: http://www.cfp.ca/content/52/10/1236.long

24. Pettifor JM. Acute lower respiratory infections in children [Editorial]. S Afr J CH. 2015 [accessed on 11 Feb 2019];9(2):35. doi: 10.7196/SAJCH.947. Available from: http://www.scielo.org.za/pdf/sajch/v9n2/01.pdf

25. Boyles TH, Brink A, Calligaro GL, et al. South African guideline for the management of community-acquire pneumonia in adults. S Afr J Infect Dis. 2018 [accessed on 15 Jan 2019];33(1):5-27. Available from: www.ncbi.nlm.nih.gov/ pmc/articles/PMC5506119/

26. Nyamande K. An approach to community-acquired pneumonia in adults. Continuing Medical Education. Sept 2013 [accessed on 11 Feb 2019];[S.I.]31(9):339-41. Available from: http://www.cmej.org.za/index.php/cmej/ article/view/2859/3186

27. Short S, Bashir H, Marshall P, et al. Institute for Clinical Systems Improvement. Diagnosis and Treatment of Respiratory IIIness in Children and Adults. 5th ed. Updated Sept 2017 [accessed on 15 Jan 2019]. Available from: https://www.icsi. org/_asset/pwyrky/Resplllness.pdf 